\title{
Al-MCM-41: An Efficient and Recyclable Heterogeneous Catalyst for the Synthesis of $\beta$-Hydroxy Thiocyanates in Water
}

\author{
Soheil Sayyahi, ${ }^{1}$ Saied Menati, ${ }^{2}$ and Mehri Karamipour ${ }^{3}$ \\ ${ }^{1}$ Department of Chemistry, Mahshahr Branch, Islamic Azad University, Mahshahr, Iran \\ ${ }^{2}$ Department of Chemistry, Khorramabad Branch, Islamic Azad University, Khorramabad, Iran \\ ${ }^{3}$ Department of Chemistry, Omidieh Branch, Islamic Azad University, Omidieh, Iran \\ Correspondence should be addressed to Soheil Sayyahi; sayyahi.soheil@gmail.com
}

Received 6 June 2012; Revised 4 August 2012; Accepted 30 August 2012

Academic Editor: Teresa Margarida Dos Santos

Copyright (C) 2013 Soheil Sayyahi et al. This is an open access article distributed under the Creative Commons Attribution License, which permits unrestricted use, distribution, and reproduction in any medium, provided the original work is properly cited.

\begin{abstract}
An efficient and green procedure has been developed for the synthesis of $\beta$-hydroxy thiocyanate by the regioselective ring opening of epoxides with $\mathrm{NH}_{4} \mathrm{SCN}$. The reaction was carried out in water without any organic solvent at $40^{\circ} \mathrm{C}$, using $\mathrm{Al}-\mathrm{MCM}-41$ (a mesoporous aluminosilicate) as catalyst. In this method, several types of epoxides carrying electron-donating or withdrawing groups were rapidly converted to the corresponding $\beta$-hydroxy thiocyanates in good from excellent yields. Various advantages associated with this protocol include simple workup procedure, short reaction times, high product yields, greater regioselectivity, and easy recovery and reusability of the catalyst.
\end{abstract}

\section{Introduction}

Chemical processes employ large amounts of hazardous and toxic solvents. One of the challenges for the chemists is to come up with new approaches that are less hazardous to human and environment. The choice of pursuing a low waste route and reusable reaction media and minimizing the economic cost and environmental impact of a chemical process is becoming ever more urgent for the future. One of the most promising approaches uses water as reaction medium. Water is an abundant, cheap, nontoxic, and nondangerous solvent [1].

From green chemistry point of view, there is an increasing demand for transformation of homogeneous into heterogeneous catalysis in organic synthesis, especially in fine chemical synthesis due to the ease with which catalysts can be separated from products and recycled [6]. Microand mesoporous materials offer unique opportunities for heterogeneous catalysis by their large surface area. Recently, a wide range of acid-base or redox catalysts have been developed by modification of such material via introducing active elements inside the pore walls [7, 8]. Mesoporous aluminosilicate, Al-MCM-41, is well known to show remarkable acidic properties. Since its pore sizes are larger than those of zeolites, bulky organic substrates can contact acid sites of mesoporous aluminosilicates [9]. Therefore, Al-MCM41 molecular sieves have been shown to catalyze several organic transformations under vapor or liquid phase reaction conditions [10-12].

Because of the importance of $\beta$-hydroxy thiocyanates in the field of synthetic organic chemistry [13] and in continuation of our ongoing effort to introduce novel catalysts for organic transformation [14-18], in this project we decided to explore the use of nanosized Al-MCM-41 as an efficient catalyst for the synthesis of $\beta$-hydroxy thiocyanates by the regioselective ring opening of epoxides under mild and ecofriendly conditions (Scheme 1).

\section{Result and Discussion}

First, the Al-MCM-41 was prepared in our laboratory according to the reported method (Figure 1) [19].

Then, the Al-MCM-41-catalyzed ring opening of epoxide was applied to synthesis of various $\beta$-hydroxy thiocyanates in the presence of thiocyanate anion in water. The reaction was 
TABLE 1: Optimization of reaction condition for thiocyanation of phenyl glycidyl ether (1 mmol).

\begin{tabular}{lccccc}
\hline Entry & Al-MCM-41/mg & $\mathrm{NH}_{4} \mathrm{SCN} / \mathrm{mmol}$ & Condition & Time (min) & Conversion \\
\hline 1 & 0 & 3 & reflux & 60 & 70 \\
2 & 100 & 3 & r.t & 60 & 30 \\
3 & 100 & 3 & $40^{\circ} \mathrm{C}$ & 30 & 100 \\
4 & 100 & 2 & $40^{\circ} \mathrm{C}$ & 30 & 45 \\
5 & 50 & 3 & $40^{\circ} \mathrm{C}$ & 30 & 70 \\
6
\end{tabular}

Table 2

Entry

1<smiles>Oc1ccccc1</smiles>

$1 b$

Time (min)

Yield $^{\mathrm{b}}(\%)$<smiles>N#CC(CO)c1ccccc1</smiles>

35

88<smiles>N#[Si]CC(O)CO[Pb]</smiles>

$2 a$

2<smiles>C=CCOCC1CO1</smiles><smiles>C=CCOCC(O)C[As]#N</smiles>

$3 a$

3<smiles>CC(C)OCC1CO1</smiles><smiles>CC(C)OCC(O)C[Si]#N</smiles>

4<smiles>CCCCOCC1CO1</smiles><smiles>CCCCOCC(O)C[As]#N</smiles>

4a

5<smiles>C=C(C)C(=O)OCC1CO1</smiles><smiles>C=C(C)C(=O)OCC(O)C[As]#N</smiles>

6<smiles>N#S[C@@H]1CCCC[C@H]1O</smiles>

6a

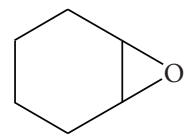

20

7

Products are known and were identified by comparison of FT-IR, ${ }^{1} \mathrm{H}$ NMR, and

${ }^{\mathrm{b}}$ Isolated yields.

optimized with respect to the amount of catalyst, thiocyanate salt, and appropriate temperature. The results are recorded in Table 1. On the basis of the experiments performed, we obtained the best results with $0.1 \mathrm{~g} \mathrm{Al-MCM}-41$ and $3 \mathrm{mmol}$ $\mathrm{NH}_{4} \mathrm{SCN}$ at $40^{\circ} \mathrm{C}$ (Table 1 , entry 3 ).
Under optimized reaction conditions, several types of epoxides carrying electron-donating or with-drawing groups were rapidly converted to the corresponding product from good to excellent yields in aqueous media at $40^{\circ} \mathrm{C}$. The results are summarized in Table 2. 


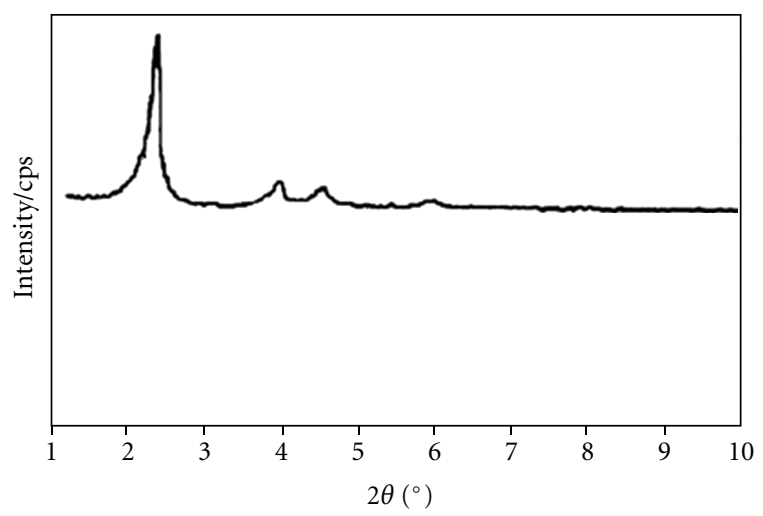

(a)

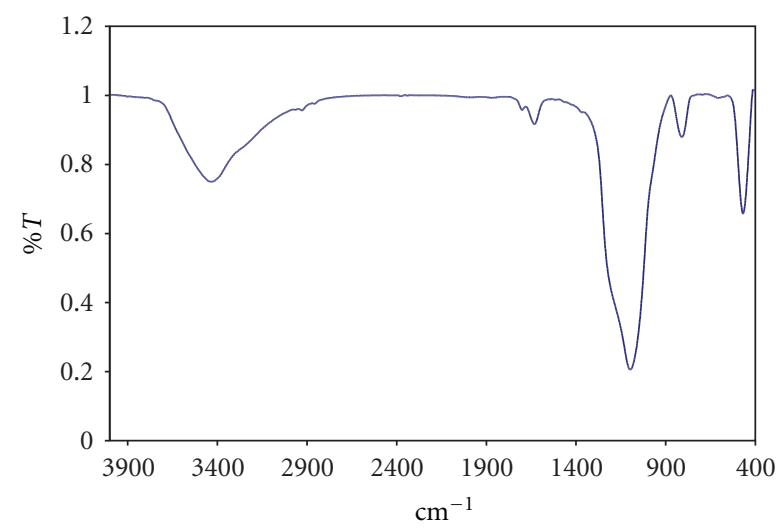

(b)

FIGURE 1: X-ray diffractogram and FTIR spectra of Al-MCM-41.

In the present conversion, epoxide is activated by the acidic proton of Al-MCM-41, which undergoes a nucleophilic attack by $\mathrm{SCN}^{-}$anion (Scheme 2).

In all cases, very clean reactions were observed, and the structures and the regiochemical ratios of products were determined by FT-IR, ${ }^{1} \mathrm{H}$ NMR, and ${ }^{13} \mathrm{C}$ NMR spectroscopy and also by comparison with authentic compounds. It is also worth mentioning that the Al-MCM-41 catalyst was easily recovered by simple filtration, and showed no appreciable loss of activity and without any variation in the reaction times or the yields of the corresponding products when recycled several times (Figure 2).

In conclusion, we have developed a novel, facile and efficient ring opening of epoxides that with $\mathrm{SCN}^{-}$as nucleophiles in the presence of Al-MCM-41. Mild reaction condition, simplicity in operation, low environmental impact and high yields of products can be considered as an advantage of this method.

\section{Experimental}

3.1. General Comments. Products were characterized by comparison of their physical data, IR, ${ }^{1} \mathrm{H}$ NMR, and ${ }^{13} \mathrm{C}$ NMR spectra with known samples. NMR spectra were recorded in $\mathrm{CDCl}_{3}$ on a Bruker Avance DPX $400 \mathrm{MHz}$ spectrometer using TMS as an internal standard. IR spectra were recorded on a BOMEM MB-Series 1998 FT-IR spectrometer.

3.2. Synthesis of Al-MCM-41. Al-MCM-41 were syntheses starting from a mixing solution of $\mathrm{NaOH}(4.04 \mathrm{~g}$ in $120 \mathrm{ml}$ distilled water) and silicic acid $(16.08 \mathrm{~g})$ at $75^{\circ} \mathrm{C}$ for $1 \mathrm{~h}$ and then, it was slowly added to cetyltrimethyl ammonium bromide $(9.0 \mathrm{~g})$ under vigorous stirring. After 1 hour, this solution was added to an aqueous suspension of aluminum sulfate drop by drop under continuous stirring. The resultant gel was transferred into a teflon-lined stainless steel autoclave under autogenous pressure and treated hydrothermally at $110^{\circ} \mathrm{C}$ for 4 days. The solid product was obtained after cooling to room temperature, filtering, washing, and drying at $110^{\circ} \mathrm{C}$ for 6 hours. Finally, the product was calcined at $500^{\circ} \mathrm{C}$ for 5 hours.

3.3. Typical Procedure for the Preparation of $\beta$-Hydroxy Thiocyanates Catalyzed by Al-MCM-41. Epoxide (1.0 mmol) was added to a suspension of Al-MCM-41 (100 mg), which was pretreated in vacuo at $120^{\circ} \mathrm{C}$ for 1 hour and $\mathrm{NH}_{4} \mathrm{SCN}$ $(228 \mathrm{mg}, 3.0 \mathrm{mmol})$ in water $(5 \mathrm{~mL})$. The mixture was magnetically stirred at $40^{\circ} \mathrm{C}$ for the time shown in Table 1 . After complete consumption of epoxide as judged by TLC (using $n$ hexane/ethylacetate (5:1) as eluent), the insoluble Al-MCM41 catalyst was filtered off and the filtrate was extracted with ether $(3 \times 5)$. The extract was dried over $\mathrm{Na}_{2} \mathrm{SO}_{4}$ and evaporated in vacuo to give the alcohols. The crude products were purified by silica gel column chromatography.

3.4. Spectral Data. 2-Hydroxy-1-phenylethyl thiocyanate 1b: IR $v_{\text {max }} / \mathrm{cm}^{-1}: 2151(\mathrm{SCN}) ;{ }^{1} \mathrm{H}-\mathrm{NMR}\left(\mathrm{CDCl}_{3}, 400 \mathrm{MHz}\right): \delta$ 4.15-4.32 (1H, m), $4.42(1 \mathrm{H}, \mathrm{m}), 4.62(1 \mathrm{H}, \mathrm{m}), 4.85(1 \mathrm{H}, \mathrm{s})$, 7.32-7.52 (5H, m, Ar- $\underline{\mathrm{H}}) ;{ }^{13} \mathrm{C}-\mathrm{NMR}\left(\mathrm{CDCl}_{3}, 100 \mathrm{MHz}\right): \delta$ $46.34\left(\mathrm{CH}_{2} \mathrm{SCN}\right), 59.70(\mathrm{CHOH}), 110.58$ (SCN), 128.57 (o$\mathrm{CH}), 129.83$ (p-CH), $129.94(m-\mathrm{CH}), 137.43(\mathrm{C})$.

3-Phenoxy-2-hydroxypropyl thiocyanate 2a: IR $v_{\max } / \mathrm{cm}^{-1}: 2156(\mathrm{SCN}) ;{ }^{1} \mathrm{H}-\mathrm{NMR}\left(\mathrm{CDCl}_{3}, 400 \mathrm{MHz}\right)$ : $\delta 3.30\left(2 \mathrm{H}, \mathrm{d}, \mathrm{CH}_{2} \mathrm{SCN}\right), 3.78(1 \mathrm{H}, \mathrm{s}, \mathrm{OH}), 4.15(2 \mathrm{H}, \mathrm{d}$, $\left.\mathrm{OCH}_{2}\right), 4.29(1 \mathrm{H}, \mathrm{m}, \mathrm{CHOH}), 6.95(2 \mathrm{H}, \mathrm{m}, \mathrm{Ar}-\underline{\mathrm{H}}), 7.02$ $(1 \mathrm{H}, \mathrm{m}, \mathrm{Ar}-\underline{\mathrm{H}}), 7.28(2 \mathrm{H}, \mathrm{m}, \mathrm{Ar}-\underline{\mathrm{H}}) ;{ }^{13} \mathrm{C}-\mathrm{NMR}\left(\mathrm{CDCl}_{3}, 100\right.$ $\mathrm{MHz}): \delta 37 . \overline{4}\left(\mathrm{CH}_{2} \mathrm{SCN}\right), 68.1(\overline{\mathrm{CHOH}}), 69.5\left(\mathrm{OCH}_{2}\right), 113.0$ $(\mathrm{SCN}), 114.6(o-\mathrm{CH}), 121.3(p-\mathrm{CH}), 129.9(m-\mathrm{CH}), 158.5$ (C).

3-Allyloxy-2-hydroxypropyl thiocyanate 3a: IR $v_{\max } / \mathrm{cm}^{-1}$ : $2155(\mathrm{SCN}) ;{ }^{1} \mathrm{H}-\mathrm{NMR}\left(\mathrm{CDCl}_{3}, 400 \mathrm{MHz}\right): \delta 3.04(1 \mathrm{H}, \mathrm{s}$, $\mathrm{OH}), 3.24\left(2 \mathrm{H}, \mathrm{d}, \mathrm{CH}_{2} \mathrm{SCN}\right), 3.53\left(2 \mathrm{H}, \mathrm{d}, \mathrm{OCH}_{2}\right), 4.05(3 \mathrm{H}$, $\left.\mathrm{m}, \mathrm{OCH}_{2} \mathrm{CHOH}\right), 5.19-5.29\left(2 \mathrm{H}, \mathrm{m},=\mathrm{CH}_{2}\right), 5.87(1 \mathrm{H}, \mathrm{m}$, $=\mathrm{CH}) ;{ }^{13} \mathrm{C}-\mathrm{NMR}\left(\mathrm{CDCl}_{3}, 100 \mathrm{MHz}\right): \delta 37.3\left(\mathrm{CH}_{2} \mathrm{SCN}\right), 69.2$ $\left(\mathrm{CH}_{2} \mathrm{O}\right), 71.1(\mathrm{CHOH}), 71.6\left(\mathrm{OCH}_{2}\right), 113.1(\mathrm{SCN}), 117.5$ $\left(\mathrm{CH}_{2}=\right), 133.7$ (=CH).

2-Hydroxy-3-isopropoxypropyl thiocyanate 4a: IR $v_{\max } / \mathrm{cm}^{-1}: 2156(\mathrm{SCN}) ;{ }^{1} \mathrm{H}-\mathrm{NMR}\left(\mathrm{CDCl}_{3}, 400 \mathrm{MHz}\right): \delta 1.18$ $\left(6 \mathrm{H}, \mathrm{d}, \mathrm{CH}_{3}\right), 2.7(1 \mathrm{H}, \mathrm{m}), 3.1(1 \mathrm{H}, \mathrm{m}), 3.18(1 \mathrm{H}, \mathrm{m}), 3.45$ $(1 \mathrm{H}, \mathrm{m}), 3.58(1 \mathrm{H}, \mathrm{m}), 4.1(1 \mathrm{H}, \mathrm{m}) ;{ }^{13} \mathrm{C}-\mathrm{NMR}\left(\mathrm{CDCl}_{3}, 100\right.$ 


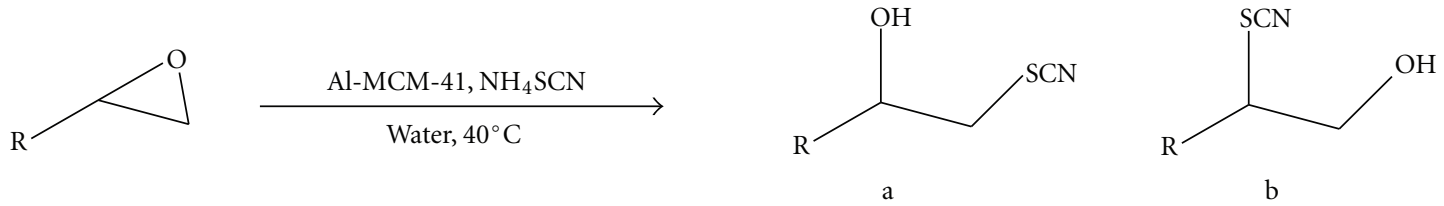

SCHEMe 1
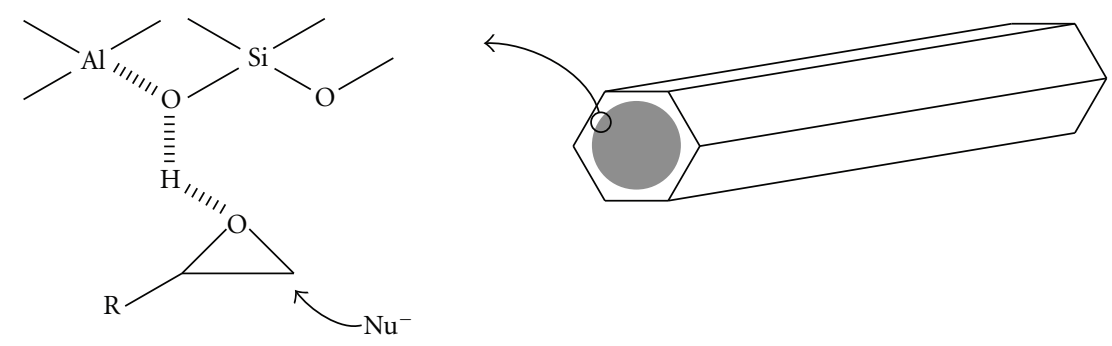

Scheme 2: Postulated roles of Al-MCM-41 in the ring opening reaction of epoxides.

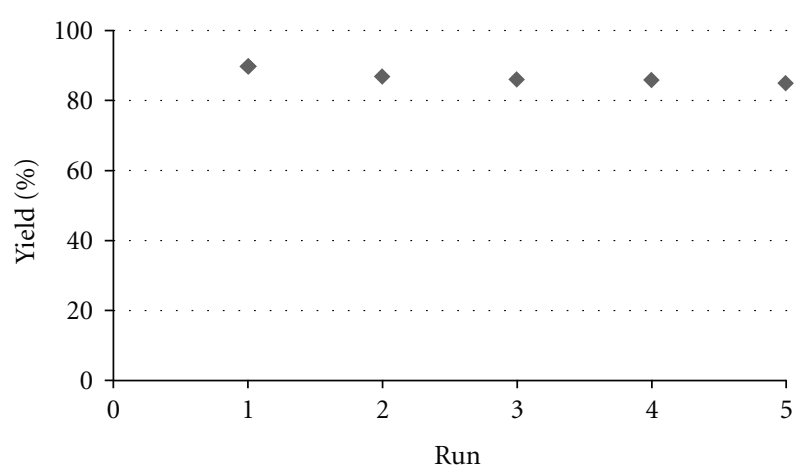

Figure 2: Synthesis of 3-phenoxy-2-hydroxypropyl thiocyanate with recovered Al-MCM-41.

$\mathrm{MHz}): \delta 21.90\left(\mathrm{CH}_{3}\right), 37.29\left(\mathrm{CH}_{2}-\mathrm{SCN}\right), 69.36(\mathrm{CHOH})$, $72.55\left(\mathrm{CH}_{2} \mathrm{O}\right), 76.60(\mathrm{CH}), 112.49(\mathrm{SCN})$.

3-Butoxy-2-hydroxypropyl thiocyanate 5a: IR $v_{\max } / \mathrm{cm}^{-1}$ : 2156 (SCN); ${ }^{1} \mathrm{H}-\mathrm{NMR}\left(\mathrm{CDCl}_{3}, 400 \mathrm{MHz}\right): \delta 0.95(3 \mathrm{H}, \mathrm{t}$, $\left.\mathrm{C}_{3}\right), 1.52-1.41\left(4 \mathrm{H}, \mathrm{m}, \mathrm{C}_{2}-\underline{\mathrm{C}}_{2}\right), 2.80(1 \mathrm{H}, \mathrm{m}, \mathrm{O} \underline{\mathrm{H}}), 3.10$ $\left(2 \mathrm{H}, \mathrm{m}, \mathrm{CH}_{2} \mathrm{SCN}\right), 3.55\left(4 \mathrm{H}, \mathrm{m}, \mathrm{CH}_{2}-\mathrm{O}-\mathrm{CH}_{2}\right), 4.15(1 \mathrm{H}$, $\mathrm{m}, \mathrm{CH}-\mathrm{OH}) ;{ }^{13} \mathrm{C}-\mathrm{NMR}\left(\mathrm{CDCl}_{3}, 100 \mathrm{MHz}\right): \bar{\delta} 13.85\left(\mathrm{CH}_{3}\right)$, $19.22\left(\mathrm{CH}_{2}-\mathrm{CH}_{3}\right), 31.50\left(\mathrm{CH}_{2}-\mathrm{CH}_{2}\right), 37.25\left(\mathrm{CH}_{2} \mathrm{SCN}\right)$, $69.15(\mathrm{CH}-\mathrm{OH}), 71.50\left(\mathrm{CH}_{2} \mathrm{O}\right), 72.0\left(\mathrm{CH}_{2} \mathrm{CHOH}\right), 112.48$ (SCN).

2-Hydroxy-3-thiocyanatopropyl methacrylate 6a: IR $v_{\max } / \mathrm{cm}^{-1}: 2157(\mathrm{SCN}) ;{ }^{1} \mathrm{H}-\mathrm{NMR}\left(\mathrm{CDCl}_{3}, 400 \mathrm{MHz}\right): \delta 1.85$ $\left(3 \mathrm{H}, \mathrm{m}, \mathrm{CH}_{3}\right), 3.01-3.18\left(2 \mathrm{H}, \mathrm{d}, \mathrm{CH}_{2} \mathrm{SCN}\right), 3.40(1 \mathrm{H}, \mathrm{m}$, $\mathrm{C} \underline{\mathrm{HOH}}), 4.13(1 \mathrm{H}, \mathrm{s}, \mathrm{OH}), 4.15\left(2 \mathrm{H}, \mathrm{d}_{1} \mathrm{OCH}_{2}\right), 5.56(1 \mathrm{H}, \mathrm{m}$, $\left.=\mathrm{CH}_{2}\right), 6.07\left(1 \mathrm{H}, \mathrm{m},=\mathrm{CH}_{2}\right) ;{ }^{13} \mathrm{C}-\mathrm{NMR}\left(\mathrm{CDCl}_{3}, 100 \mathrm{MHz}\right)$ : $\delta 18.4\left(\mathrm{CH}_{3}\right), 37.3\left(\mathrm{CH}_{2} \mathrm{SCN}\right), 66.1\left(\mathrm{OCH}_{2}\right), 68.1(\mathrm{CHOH})$, $112.8(\mathrm{SCN}), 126.6\left(\mathrm{CH}_{2}=\right), 135.2(=\mathrm{CH}), 167.1(\mathrm{C}=\mathrm{O})$.

2-Hydroxycyclohexyl thiocyanate 7a: IR $v_{\max } / \mathrm{cm}^{-1}: 2151$ (SCN); ${ }^{1} \mathrm{H}-\mathrm{NMR}\left(\mathrm{CDCl}_{3}, 400 \mathrm{MHz}\right): \delta$ 1.21-1.29 $(4 \mathrm{H}, \mathrm{m}$, $\left.\mathrm{CH}_{2} \mathrm{CH}_{2} \mathrm{CHSCN}\right), 1.69\left(2 \mathrm{H}, \mathrm{m}, \mathrm{CH}_{2} \mathrm{CH}_{2} \mathrm{CHOH}\right), 1.98(2 \mathrm{H}$, $\left.\mathrm{m}, \mathrm{C}_{2} \mathrm{CHOH}\right), 3.14(1 \mathrm{H}, \mathrm{s}, \mathrm{O} \underline{\mathrm{H}}), 3.16(1 \mathrm{H}, \mathrm{m}, \mathrm{C} \underline{\mathrm{HSCN}})$,
$3.34(1 \mathrm{H}, \mathrm{m}, \mathrm{CHOH}) .{ }^{13} \mathrm{C}-\mathrm{NMR}\left(\mathrm{CDCl}_{3}, 100 \mathrm{MHz}\right): \mathrm{d}$ $23.1\left(\mathrm{CH}_{2} \mathrm{CH}_{2}\right), 25.2\left(\mathrm{CH}_{2} \mathrm{CH}_{2}\right), 30.0\left(\mathrm{CH}_{2} \mathrm{CHSCN}\right), 31.4$ $\left(\mathrm{CH}_{2} \mathrm{CHOH}\right), 51.5(\mathrm{CHSCN}), 79.1(\mathrm{CHOH}), 110.6(\mathrm{SCN})$.

\section{Acknowledgment}

The financial support of this work by Islamic Azad University, Mahshahr Branch is greatly appreciated.

\section{References}

[1] H. C. Hailes, "Reaction solvent selection: the potential of water as a solvent for organic transformations," Organic Process Research and Development, vol. 11, no. 1, pp. 114-120, 2007.

[2] R. Eisavi, B. Zeynizadeh, and M. M. Baradarani, "Fast, efficient and regioselective conversion of epoxides to $\beta$-hydroxy thiocyanates with $\mathrm{NH}_{4} \mathrm{SCN}$ /zeolite molecular sieve $4 \AA$ under solvent-free conditions," Bulletin of the Korean Chemical Society, vol. 32, no. 2, pp. 630-634, 2011.

[3] A. R. Kiasat and M. F. Mehrjardi, "PEG- $\mathrm{SO}_{3} \mathrm{H}$ as soluble acidic polymeric catalyst for regioselective ring opening of epoxides: a high-efficient synthetic approach to $\beta$-hydroxy thiocyanates," Synthetic Communications, vol. 38, no. 17, pp. 2995-3002, 2008.

[4] B. Tamami and H. Mahdavi, "Synthesis of thiocyanohydrins from epoxides using quaternized amino functionalized crosslinked polyacrylamide as a new solid-liquid phase-transfer catalyst," Tetrahedron Letters, vol. 43, no. 35, pp. 6225-6228, 2002.

[5] H. Sharghi, A. S. Beni, and R. Khalifeh, "Synthesis of some novel thioxanthenone-fused azacrown ethers, and their use as new catalysts in the efficient, mild, and regioselective conversion of epoxides to $\beta$-hydroxy thiocyanates with ammonium thiocyanate," Helvetica Chimica Acta, vol. 90, no. 7, pp. 1373-1385, 2007.

[6] S. Li, Q. Xu, J. Chen, and Y. Guo, "Study and characterization of Al-MCM-41 prepared with the assistance of supercritical $\mathrm{CO}_{2}$," Industrial and Engineering Chemistry Research, vol. 47, no. 21, pp. 8211-8217, 2008. 
[7] A. Taguchi and F. Schüth, "Ordered mesoporous materials in catalysis," Microporous and Mesoporous Materials, vol. 77, no. 1, pp. 1-45, 2005.

[8] F. Ma, S. Chen, Y. Wang, F. Chen, and W. Lu, "Characterization of redox and acid properties of mesoporous $\mathrm{Cr}-\mathrm{TiO}_{2}$ and its efficient performance for oxidative dehydrogenation of propane," Applied Catalysis A, vol. 427-428, pp. 145-154, 2012.

[9] S. Ito, H. Yamaguchi, Y. Kubota, and M. Asami, "Mesoporous aluminosilicate-catalyzed allylation of aldehydes with allylsilanes," Tetrahedron Letters, vol. 50, no. 24, pp. 2967-2969, 2009.

[10] S. Ito, A. Hayashi, H. Komai, H. Yamaguchi, Y. Kubota, and M. Asami, "Mesoporous aluminosilicate-catalyzed allylation of carbonyl compounds and acetals," Tetrahedron, vol. 67, no. 11, pp. 2081-2089, 2011.

[11] K. Iwanami, H. Seo, J. C. Choi, T. Sakakura, and H. Yasuda, "AlMCM-41 catalyzed three-component Strecker-type synthesis of $\alpha$-aminonitriles," Tetrahedron, vol. 66, no. 10, pp. 1898-1901, 2010.

[12] M. Selvaraj, S. H. Jeon, J. Han, P. K. Sinha, and T. G. Lee, "A novel route to produce 4- $t$-butyltoluene by $t$-butylation of toluene with $t$-butylalcohol over mesoporous Al-MCM-41 molecular sieves," Applied Catalysis A, vol. 286, no. 1, pp. 44-51, 2005.

[13] A. R. Kiasat and M. Fallah-Mehrjardi, " $\mathrm{B}\left(\mathrm{HSO}_{4}\right)_{3}$ : a novel and efficient solid acid catalyst for the regioselective conversion of epoxides to thiocyanohydrins under solvent-free conditions," Journal of the Brazilian Chemical Society, vol. 19, no. 8, pp. 1595-1599, 2008.

[14] A. R. Kiasat and S. Sayyahi, "Immobilization of $\beta$-cyclodextrin onto Dowex resin as a stationary microvessel and phase transfer catalyst," Catalysis Communications, vol. 11, no. 5, pp. 484-486, 2010.

[15] A. R. Kiasat, R. Badri, B. Zargar, and S. Sayyahi, "Poly(ethylene glycol) grafted onto dowex resin: an efficient, recyclable, and mild polymer-supported phase transfer catalyst for the regioselective azidolysis of epoxides in water," Journal of Organic Chemistry, vol. 73, no. 21, pp. 8382-8385, 2008.

[16] A. R. Kiasat, R. Badri, and S. Sayyahi, "Polymer supported cyanide as an efficient catalyst in benzoin condensation: an efficient route to $\alpha$-hydroxy carbonyl compounds," Bulletin of the Korean Chemical Society, vol. 30, no. 5, pp. 1164-1166, 2009.

[17] S. Sayyahi and J. Saghanezhad, "An efficient method for synthesis of phenacyl derivatives under homogeneous phase transfer catalyst condition in aqueous media," Chinese Chemical Letters, vol. 22, no. 3, pp. 300-302, 2011.

[18] M. Gorjizadeh and S. Sayyahi, "A novel and efficient synthesis of alkyl thiocyanates from alkyl halides in water using phase transfer catalysts," Chinese Chemical Letters, vol. 22, no. 6, pp. 659-662, 2011.

[19] T. M. Salama, I. O. Ali, and H. A. Gumaa, "Synthesis and characterization of $\mathrm{Cu}(\mathrm{I})$-salen complex immobilized aluminosilicate MCM-41," Microporous and Mesoporous Materials, vol. 113, no. 1-3, pp. 90-98, 2008. 

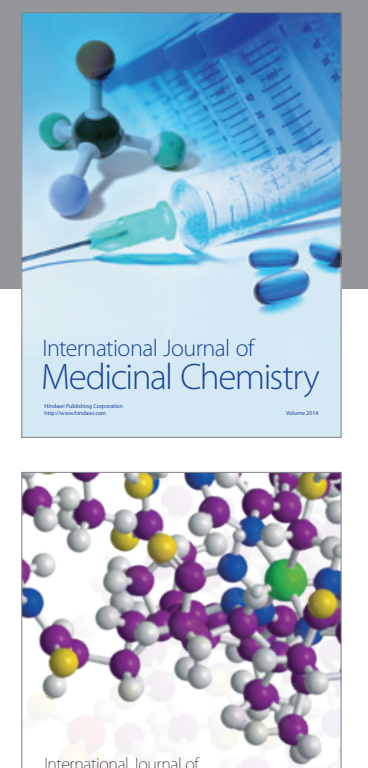

\section{Carbohydrate} Chemistry

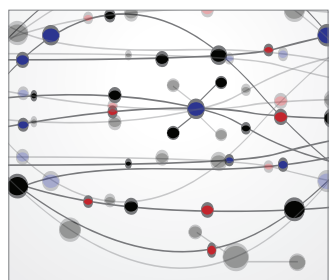

The Scientific World Journal
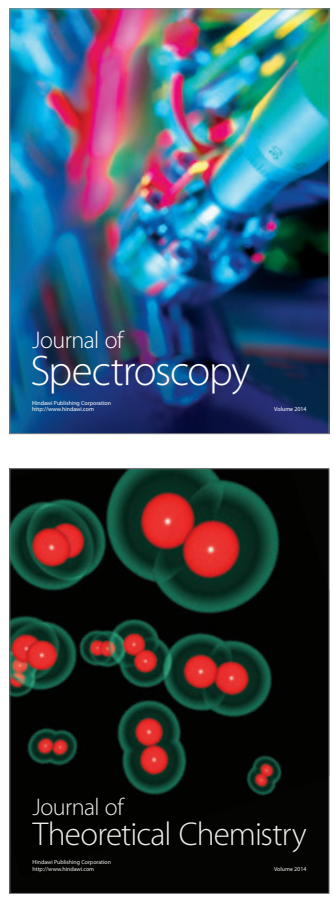
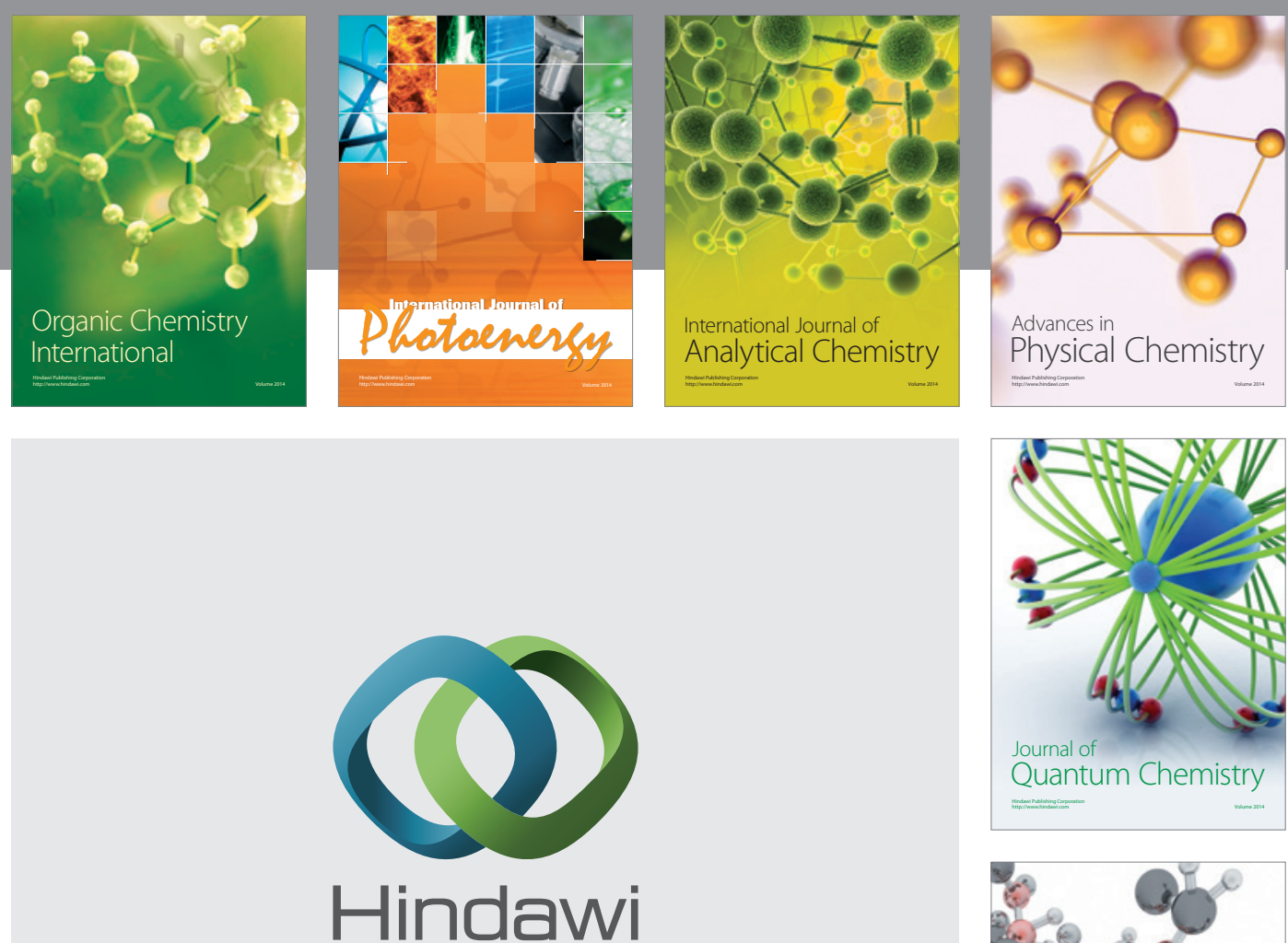

Submit your manuscripts at

http://www.hindawi.com

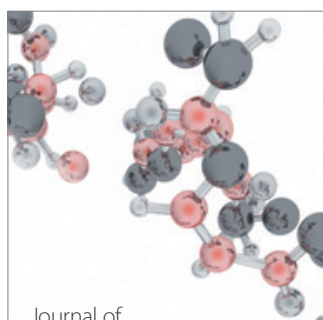

Analytical Methods

in Chemistry

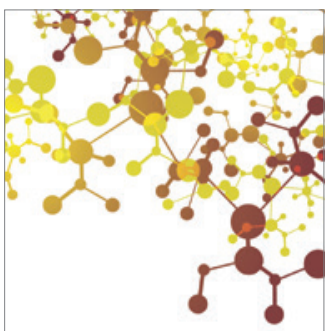

Journal of

Applied Chemistry

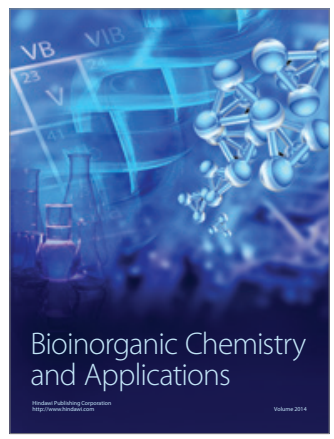

Inorganic Chemistry
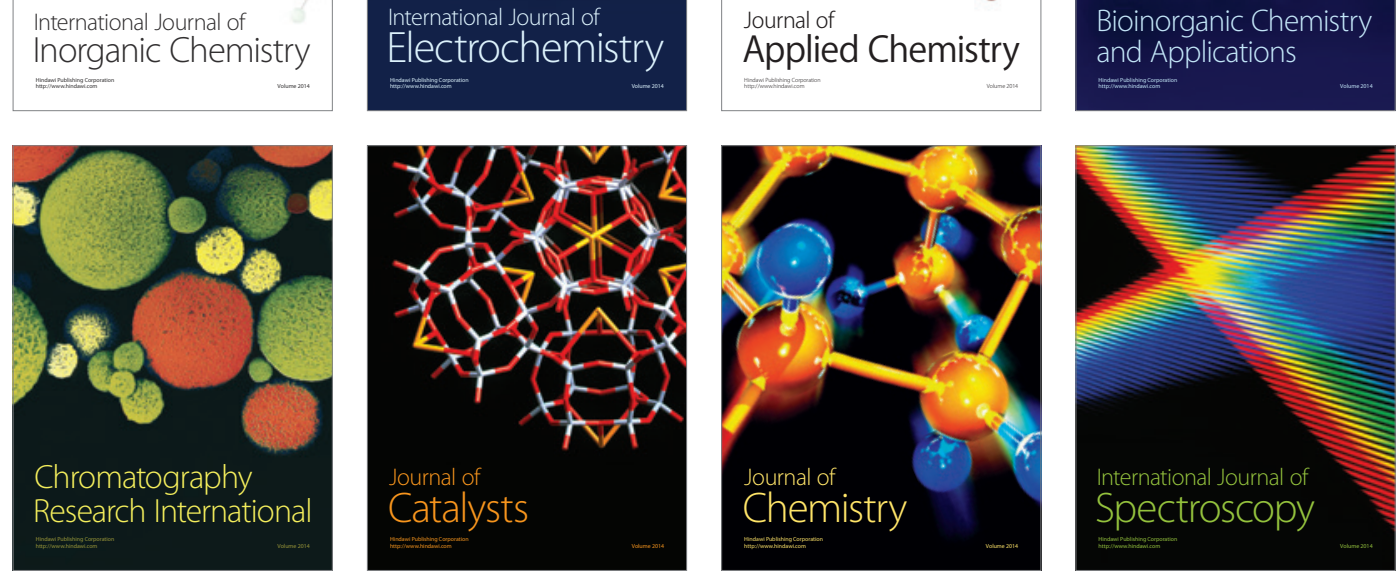